\title{
The impact of COVID-19 on traumatic eye emergencies needing surgery
}

\author{
Emma Samia-Aly (i] ${ }^{1} \cdot$ George Moussa $\mathbb{i}^{1} \cdot$ Soon Wai $\mathrm{Ch}^{\prime} \mathbf{n g}^{1}$
}

Received: 21 March 2021 / Revised: 28 March 2021 / Accepted: 15 April 2021 / Published online: 6 May 2021

(c) Crown 2021

\section{To the Editor:}

We read with interest the recently published paper on the changing trends of ocular trauma during COVID-19 by Pellegrini et al. [1]. Although the burden of COVID-19 on health systems has increased, many have reported a trend in decreasing attendance to the emergency department; a $57 \%$ decrease across the United Kingdom [2, 3]. This was reflected by Pellegrini et al. [1] reporting a $68.4 \%$ reduction in the number of eye injuries.

In our retrospective, continuous comparative analysis of all trauma patients who presented to Birmingham and Midland Eye Centre, UK, a tertiary eye emergency department, we focus further on the major injuries that necessitated emergency surgical intervention. These injuries included eyelid lacerations, corneal and globe perforations, and retained intraocular foreign bodies (IOFB). Our study covers a similar time period, however, applies to the UK lockdown period from the 16th of March till the 30th of June 2020 when measures were starting to be relaxed. They were compared with patients during the same time period in the previous year, 2019. All data were extracted from electronic patient records (Medisoft Ophthalmology, Medisoft Limited, Leeds, UK) and analyses were performed using SPSS Statistics for V.25.0 (IBM Corp., Armonk NY).
During this time period, we report 13 surgical trauma cases out of 13,134 attendances in 2019 compared to 14 out of 6254 attendances in 2020. This represents a 52.4\% reduction in patients attending the emergency department and a relative increase in surgical trauma cases by 2.3 times $(p=0.048)$. Table 1 shows the demographics and clinical characteristics of both groups. There was no significant difference in the visual outcomes achieved post-surgery. Pre COVID-19, significantly more of these injuries were being sustained during a fall (0.038), whilst during COVID there were significantly more injuries being sustained at home $(p=0.013)$, which is reflected by Pellegrini et al. It was however worrying that there was an increase in assaultrelated injuries, particularly those sustained at home. Several papers have reported an increase in domestic abuse during the lockdown, due to social isolation, external economic pressures and less support available, which may explain the changes noted in our study [4]. Although our study concurs with Pellegrini et al with regards to an overall reduction in attendance with more injuries being sustained at home, we found that those sustaining major injuries were still seeking medical attention. It is therefore reassuring that in the UK, the stay-at-home advice was not discouraging those with eye trauma necessitating surgical intervention to present to the eye department.
Emma Samia-Aly

emmasamiaaly@gmail.com

1 Birmingham and Midland Eye Centre, Sandwell and West Birmingham Hospitals NHS Trust, Dudley Road, Birmingham B18 7QH, UK 
Table 1 Demographics and clinical characteristics of cases Pre and Post COVID-19 era.

\begin{tabular}{|c|c|c|c|c|}
\hline & Total & $\begin{array}{l}\text { Pre COVID-19 } \\
\text { (March 16-June 30, 2019) }\end{array}$ & $\begin{array}{l}\text { During COVID-19 } \\
\text { (March 16-June 2020) }\end{array}$ & $p$ Value \\
\hline $\begin{array}{l}\text { Total emergency } \\
\text { attendance }\end{array}$ & 19,388 & 13,134 & 6254 & - \\
\hline Total surgical trauma (\%) & $27(0.14 \%)$ & $13(0.10 \%)$ & $14(0.22 \%)$ & $* 0.048$ \\
\hline \multicolumn{5}{|l|}{ Injury type } \\
\hline Globe perforation & $13(48 \%)$ & $4(31 \%)$ & $9(64 \%)$ & 0.128 \\
\hline Sclero-corneal laceration & $6(22 \%)$ & $4(31 \%)$ & $2(14 \%)$ & 0.385 \\
\hline Lid laceration & $5(19 \%)$ & $3(23 \%)$ & $2(14 \%)$ & 0.648 \\
\hline IOFB & $3(11 \%)$ & $2(15 \%)$ & $1(7 \%)$ & 0.596 \\
\hline \multicolumn{5}{|l|}{ Place of injury } \\
\hline Occupational & $2(7 \%)$ & $2(15 \%)$ & $0(0 \%)$ & 0.222 \\
\hline Residential & $19(70 \%)$ & $6(46 \%)$ & $13(93 \%)$ & $* 0.013$ \\
\hline Not specified & $6(22 \%)$ & $5(38 \%)$ & $1(7 \%)$ & - \\
\hline \multicolumn{5}{|l|}{ Activity type } \\
\hline $\begin{array}{l}\text { Home activity (DIY/ } \\
\text { gardening, etc.) }\end{array}$ & $14(42 \%)$ & $5(39 \%)$ & $9(64 \%)$ & 0.257 \\
\hline Assault & $7(26 \%)$ & $2(15 \%)$ & $5(36 \%)$ & 0.385 \\
\hline Fall & $4(15 \%)$ & $4(31 \%)$ & $0(0 \%)$ & $* 0.041$ \\
\hline Occupational & $2(7 \%)$ & $2(15 \%)$ & $0(0 \%)$ & 0.222 \\
\hline \multicolumn{5}{|l|}{ Grade of surgeon } \\
\hline Speciality trainee $3-7$ & $14(52 \%)$ & $10(77 \%)$ & $4(29 \%)$ & $* 0.021$ \\
\hline Fellow & $7(26 \%)$ & $1(8 \%)$ & $6(43 \%)$ & 0.077 \\
\hline Consultant & $6(22 \%)$ & $2(15 \%)$ & $4(29 \%)$ & 0.648 \\
\hline Laterality (\% Right) & $12(44 \%)$ & $6(46 \%)$ & $6(43 \%)$ & 1.000 \\
\hline Gender ( $\%$ Male) & $19(70 \%)$ & $8(62 \%)$ & $11(79 \%)$ & 0.420 \\
\hline \multicolumn{5}{|l|}{ Ethnicity } \\
\hline White & $13(48 \%)$ & $8(62 \%)$ & $5(36 \%)$ & 0.257 \\
\hline South Asian & $2(7 \%)$ & $0(0 \%)$ & $2(14 \%)$ & 0.481 \\
\hline Black & $3(11 \%)$ & $2(15 \%)$ & $1(7 \%)$ & 0.596 \\
\hline Mixed & $2(7 \%)$ & $2(15 \%)$ & $0(0 \%)$ & 0.222 \\
\hline Other & $7(26 \%)$ & $1(8 \%)$ & $6(43 \%)$ & 0.077 \\
\hline Age & $39(28-57)$ & $32(15-51)$ & $45(35-57)$ & 0.220 \\
\hline PreOp VA (LogMAR) & $1.00(0.18-2.70)$ & $0.40(0.18-1.00)$ & $2.40(1.00-2.70)$ & 0.091 \\
\hline PostOpVA (LogMAR) & $0.78(0.18-2.70)$ & $0.30(0.18-1.78)$ & $2.55(0.24-2.85)$ & 0.235 \\
\hline $\begin{array}{l}\text { LogMAR Gain } \\
\text { (LogMAR) }\end{array}$ & $0.00(0.00-0.30)$ & $0.22(-0.12-0.40)$ & $0.00(0.00-0.00)$ & 0.797 \\
\hline
\end{tabular}

Age and LogMAR are reported as median (interquartile range), with $p$ values from Mann-Whitney $U$ tests, or as $N(\%)$, with $p$ values from Fisher's exact tests for two groups or chi-squared test for $>2$ groups.

${ }^{*} p$ Values significant at $p<0.05$
Author contributions All authors have made substantial contributions to all of the following: (1) the conception and design of the study, or acquisition of data, or analysis and interpretation of data, (2) drafting the article or revising it critically for important intellectual content, and (3) final approval of the version to be submitted.

\section{Compliance with ethical standards}

Conflict of interest The authors declare no competing interests.

Publisher's note Springer Nature remains neutral with regard to jurisdictional claims in published maps and institutional affiliations.

\section{References}

1. Pellegrini M, Roda M, Di Geronimo N, Lupardi E, Giannaccare G, Schiavi C. Changing trends of ocular trauma in the time of COVID-
19 pandemic. Eye (London). 2020;34(Jul):1248-50. https://doi.org/ 10.1038/s41433-020-0933-x.

2. Poyser A, Deol SS, Osman L, Kuht HJ, Sivagnanasithiyar T, Manrique R, et al. Impact of COVID-19 pandemic and lockdown on eye emergencies. Eur J Ophthalmol. 2020 Nov:1120672120974944. https://doi.org/10.1177/1120672120974944.

3. Kelly E and Firth Z The Health Foundation. How Is COVID-19 Changing the Use of Emergency Care? 15 May 2020. See https://www.health.org.uk/news-and-comment/charts-and-infogra phics/how-is-covid-19-changing-the-use-of-emergency-care.

4. Vieira PR, Garcia LP, Maciel ELN. Isolamento social e o aumento da violência doméstica: o que isso nos revela? [The increase in domestic violence during the social isolation: what does it reveals?]. Rev Bras Epidemiol 2020;23(Apr):e200033. https://doi. org/10.1590/1980-549720200033. Portuguese 